Portland State University

PDXScholar

$5-1983$

Nest Success and Nesting Habits of Eastern

Kingbirds and Other Flycatchers

Michael T. Murphy

Portland State University, murphym@pdx.edu

Follow this and additional works at: https://pdxscholar.library.pdx.edu/bio_fac

Part of the Biology Commons, and the Ornithology Commons

Let us know how access to this document benefits you.

Citation Details

Murphy, M. T. (1983). Nest success and nesting habits of Eastern Kingbirds and other flycatchers. Condor, 208-219.

This Article is brought to you for free and open access. It has been accepted for inclusion in Biology Faculty Publications and Presentations by an authorized administrator of PDXScholar. Please contact us if we can make this document more accessible: pdxscholar@pdx.edu. 


\title{
NEST SUCCESS AND NESTING HABITS OF EASTERN KINGBIRDS AND OTHER FLYCATCHERS
}

\author{
MICHAEL T. MURPHY
}

\begin{abstract}
Patterns of nest placement and its relationship to nest success in the Eastern Kingbird (Tyrannus tyrannus) were studied in populations breeding in New York and Kansas. Data were augmented with information on nest placement in other open-nesting tyrannids in order to examine the hypothesis that these flycatchers place their nests chiefly so as to conceal them from predators. Nesting success was significantly greater in New York than in Kansas but was relatively high in both populations, as is apparently true of North American breeding flycatchers in general. Geographic variation in nest placement in the Eastern Kingbird was relatively small and statistical comparisons of failed and successful nests indicated that nests placed at mid-heights in the tree. and
\end{abstract}

usea sites. Increased vegetative cover around the nest and a greater number or supporting branches for the nest were also associated with success, and it is their interaction with nest height and distance from the canopy edge that is apparently most important in determining success. Most tyrant flycatchers nest several meters or more above the ground, and interspecific variation in nest placement matches the range of sites used by Eastern Kingbirds. Aggressive nest defense is apparently characteristic of the family, and average nest height is also positively correlated with length of the nestling period. These facts support the predator-avoidance hypothesis and suggest that nest placement habits and aggressive nest defense are means by which opennesting birds can reduce rates of nestling mortality.

Nest site selection in birds can be an important determinant of reproductive success by affecting losses caused by predators and weather, the two most important causes of nest failure (Nolan 1963, Ricklefs 1969a). Except for the well-known differences in the breeding biology of cavity- and open-nesting birds (von Haartman 1957, Lack 1968), few studies of temperate-zone breeding passerines have related aspects of nest placement to the species' overall breeding habits. If species with long nesting periods placed their nests in cryptic, easily defended or inaccessible sites, they could counteract the increased probability of predators finding the nest before the young fledge. This hypothesis has yet to be examined for temperate-zone breeding passerines, yet is presumably the basis for the great diversity of nesting habits in tropical breeding land birds (Ricklefs 1969a).

As part of a geographic comparison of the breeding biology of the Eastern Kingbird ( $T y$ rannus tyrannus), I collected data on nest placement and success. Eastern Kingbird nests are relatively conspicuous and are typically placed on horizontal branches close to the canopy edge (Davis 1941, Bent 1942, Pettingill 1973). Nestling kingbirds develop slowly (Murphy, in press) and eggs and nestlings are exposed in the nest for up to 39 days. I therefore predicted that nest placement would be important in determining the reproductive success of Eastern Kingbirds. Furthermore, since slow nestling growth and long periods of nest occupancy are typical of most tyrannids (Ricklefs 1976; Murphy, in press), nest placement should be especially important in this family and reflect the need to reduce nest losses. I tested these hypotheses using data on nest placement and success in Eastern Kingbirds, and comparative data from the literature.

\section{STUDY AREA AND METHODS}

I studied the breeding biology of Eastern Kingbirds in western New York and eastern Kansas from May through August, 1979 and 1980, respectively. The center of the New York research site was located midway between the towns of Eden and Angola, Erie Co. $\left(42^{\circ} 40^{\prime} \mathrm{N}\right.$, $78^{\circ} 57^{\prime} \mathrm{W}$ ) and was approximately $16 \mathrm{~km}$ from Lake Erie. In Kansas, I concentrated research in an area $6.5 \mathrm{~km}$ west of Lawrence, Douglas Co., near Clinton Lake $\left(38^{\circ} 57^{\prime} \mathrm{N}, 95^{\circ} 19^{\prime} \mathrm{W}\right)$. The study site in New York encompassed the adjacent lands $0.5 \mathrm{~km}$ on either side of $45 \mathrm{~km}$ of country roads, plus several larger isolated areas (range of 2-4 ha). My study site in Kansas included the adjacent lands $0.5 \mathrm{~km}$ on either 
side of country roads $(30 \mathrm{~km})$, plus an intensively studied area measuring $1.6 \times 0.8 \mathrm{~km}$. My methods preclude accurate estimates of density, but breeding pairs seemed about 1.5 to 2 times as common in Kansas as in New York.

At each nest I recorded the species of the nest tree, and six nest placement variables: nest height $(\mathrm{m})$; distance from top of tree to nest $(\mathrm{m})$; distance from nest to center of tree (m); horizontal distance from nest to outer perimeter of canopy $(\mathrm{m})$; number of branches or twigs supporting the nest; and vegetative cover within an imaginary sphere $20 \mathrm{~cm}$ in radius around the nest. Relative nest height (nest height/tree height) and relative distance from the center of the tree (distance from center of tree to nest/ distance from center of tree to canopy edge) were also calculated. Cover was estimated by placing a compass on the nest surface and ranking the quality of the cover for the four cardinal compass directions and directly over the nest. Cover quality was scored as follows: $0-25 \%$ cover, scored $0.0 ; 25-75 \%$ cover, scored $0.5 ; 75-100 \%$ cover, scored 1.0 . Scores were then summed to give an overall estimate of the degree of nest concealment (maximum of 5.0). Inaccessible nests were examined using an extensible mirror-and-pole apparatus. Distances and heights, later converted to meters, were measured to the nearest 0.5 foot using a pole marked off in feet, by climbing the tree and measuring distances directly, or using a range-finder and clinometer.

A successful nest was one that fledged at least one nestling. At both sites I found more than one-half of the nests before incubation started, and for these I divided the number of successful nests by the total number $(\mathrm{S} / n)$ to estimate success. I also calculated nest success using the entire sample and correcting for exposure time (Mayfield 1961). The status of most nests was checked every two to three days. The standard error of the estimated success rate and $95 \%$ confidence limits were also calculated (Johnson 1979). Nest failures were categorized as being due to either predation, weather, desertion, failure of eggs to hatch, or loss of an adult. If an entire nest and its contents disappeared I assumed that it was destroyed by weather. If nest contents were missing but the nest was relatively undisturbed I assumed predation had occurred. Death of nestlings due to overexposure to the sun also left the nest undisturbed. In these cases, where it was known or strongly suspected, losses were attributed to weather.

Univariate comparisons of nest placement variables between New York and Kansas and between successful and failed nests within each site were made using the Student's $t$-test. Relative nest height and relative distance from the center of the tree to the canopy were arc-sine transformed before testing. The homogeneity of variances was tested using the $F_{\max }$-test (So$\mathrm{kal}$ and Rohlf 1981). If variances were heteroscedastic, an approximate $t$-test based on the assumption of unequal variances was used to test for significant differences between means (Sokal and Rohlf 1981: 408).

If a nest's success depends upon its placement, it is likely that numerous variables, of which I have measured or generated eight, interact to ultimately determine the nest's fate. In order to improve ecological interpretability, I reduced the number of variables to a few mutually independent linear combinations of the original correlated variables using principal component analysis (PCA; BMDP4M, Dixon and Brown 1979). Because of the diverse nature of the data (i.e., counts, lengths, etc.), variables were standardized by extracting the principal components from a correlation matrix. However, because standardization based on the total variance tends to de-emphasize characters with high variance, I further standardized variables on the basis of the pooled, weighted within-group variances for successful and failed nests (Rohwer and Kilgore 1973). This procedure is appropriate when PCA is being used to separate groups where between-group variances may be large compared to within-group variances, since the former variables are those best able to differentiate between groups (see Rohwer and Kilgore 1973).

An adaptively based predator avoidance theory for nest site selection predicts a direct relationship between duration of the nestling period and nest height. To test this hypothesis I used literature sources to generate a correlation between nestling period length and nest site characteristics for species with information available. In this analysis, the duration of the nestling period used was the most commonly reported period. For nest height, I calculated the weighted average of all reports of nest height for each species for the correlation with nestling period length.

\section{RESULTS}

\section{NEST SUCCESS}

Estimates of nest success at the two sites indicated that breeding success of Eastern Kingbirds was relatively high for an open-nesting passerine (Table 1; see Ricklefs 1969a for comparative data). Accurate geographic comparisons without estimates of annual variation in success are probably not possible, but nest suc- 
TABLE 1. Estimates of nest success, daily rates of nest mortality, and sources of nest failure in Eastern Kingbirds breeding in New York and Kansas. Sample sizes in parentheses.

\begin{tabular}{|c|c|c|}
\hline & New York & Kansas \\
\hline $\begin{array}{l}\text { Nests found prior to the } \\
\text { start of incubation }{ }^{\mathrm{a}}\end{array}$ & $58.8 \%(34)$ & $31.4 \%(35)$ \\
\hline Mayfield estimate $^{b}$ & $57.7 \%(57)$ & $36.3 \%(52)$ \\
\hline $95 \%$ confidence interval ${ }^{c}$ & $50.7-65.7 \%$ & $30.2-43.5 \%$ \\
\hline \multicolumn{3}{|l|}{ Sources of failure } \\
\hline Predation & $72.2 \%(13)$ & $57.9 \%(22)$ \\
\hline Weather & $16.7 \%(3)$ & $31.6 \%(12)$ \\
\hline Failure to hatch & $5.6 \%(1)$ & $2.6 \%(1)$ \\
\hline Loss of an adult & $5.6 \%(1)$ & $0.0 \%(0)$ \\
\hline Desertion & $0.0 \%(0)$ & $7.9 \%(3)$ \\
\hline $\begin{array}{l}\text { Daily nest mortality } \\
\text { rate }^{\text {d }}\end{array}$ & 1.59 & 3.08 \\
\hline
\end{tabular}

cess was $59 \%$ greater in New York than in Kansas (for nests found before the start of incubation, $t=2.32$, $\mathrm{df}=67, P<0.05$ ). A possible cause for the lower success in Kansas may have been the more frequent nest visits that I made there (nearly every day for many nests). Frequent nest visits have been known to cause increased losses to predators (Bart 1978).

Predation on Eastern Kingbird nests was the major cause of failure in both New York and Kansas, followed by losses due to weather (Table 1). Losses due to weather resulted from nests being blown out of trees by strong winds, or death of nestlings due to direct exposure to intense sunlight. The latter phenomenon was limited to nestlings that were unable to regulate their temperature effectively (Murphy, unpubl. data)-nestlings that were less than seven days old ( $n=$ all nestlings in three nests). Seldom was I able to attribute nest losses to specific predators, but the majority of losses were most likely the result of avian or mammalian predators. Known instances included predation on a brood by an American Kestrel (Falco sparverius) in New York and destruction of a clutch of eggs by a fox squirrel (Sciurus niger) in Kansas. I suspect that squirrels are important nest predators for aboreal-nesting species in Kansas, since I also observed predation on a Northern Oriole (Icterus galbula) nest by a fox squirrel. Other nests probably were lost to American Crows (Corvus brachyrhynchos), since I have observed crows searching through vegetation in trees in the vicinity of kingbird nests in apparent attempts to locate the nests.

Similarly, nest success among other north temperate breeding tyrannids also appears to be relatively high (Table 2 ). The mortality rate that I recorded in Kansas in 1980 (3.08\%/day) was next to the highest of the 14 records for open-nesting species. The average daily mortality rate for the nine open-nesting species listed in Table $2(\bar{x}=1.77, \mathrm{SD}=0.793, n=$ 14 ) is intermediate with respect to the average daily mortality rates for hole- and niche-nesting birds $(\bar{x}=1.02, n=7$; Ricklefs 1969a) as compared to above-ground-nesting birds $(\bar{x}=$ $2.27, n=8$, Ricklefs 1969a [mortality rate for

TABLE 2. Nest success and daily mortality rates of tyrant flycatchers breeding in North America.

\begin{tabular}{|c|c|c|c|c|c|c|}
\hline Species & $\begin{array}{c}\text { Sample } \\
\text { size }\end{array}$ & $\begin{array}{l}\text { Nesting } \\
\text { cycle length } \\
\text { (days) }\end{array}$ & $\begin{array}{c}\text { Nestling } \\
\text { period length } \\
\text { (days) }\end{array}$ & $\begin{array}{l}\text { Percent } \\
\text { success }\end{array}$ & $\begin{array}{l}\text { Mortality } \\
\text { rate (\%/day) }\end{array}$ & Reference \\
\hline $\begin{array}{l}\text { Scissor-tailed Flycatcher } \\
\text { (Tyrannus forficatus) }\end{array}$ & 16 & 33 & 16 & 81.2 & 0.63 & Fitch 1950 \\
\hline $\begin{array}{l}\text { Western Kingbird } \\
\quad(T . \text { verticalis })\end{array}$ & $\begin{array}{l}46 \\
23\end{array}$ & $\begin{array}{l}35 \\
35\end{array}$ & $\begin{array}{l}16.5 \\
16.5\end{array}$ & $\begin{array}{l}56.5 \\
56.7\end{array}$ & $\begin{array}{l}1.65 \\
1.64\end{array}$ & $\begin{array}{l}\text { Goldberg } 1979 \\
\text { Cuesta } 1974\end{array}$ \\
\hline $\begin{array}{l}\text { Cassin's Kingbird } \\
(T . \text { vociferans })\end{array}$ & 36 & 35 & 16.5 & 47.2 & 2.18 & Goldberg 1979 \\
\hline Eastern Kingbird & $\begin{array}{l}57 \\
52\end{array}$ & $\begin{array}{l}35.5 \\
33\end{array}$ & $\begin{array}{l}17 \\
16\end{array}$ & $\begin{array}{l}57.7^{\mathrm{a}} \\
37.3^{\mathrm{a}}\end{array}$ & $\begin{array}{l}1.59 \\
3.08\end{array}$ & $\begin{array}{l}\text { This study, New York } \\
\text { This study, Kansas }\end{array}$ \\
\hline $\begin{array}{l}\text { Eastern Wood-Pewee } \\
\text { (Contopus virens) }\end{array}$ & 6 & 34 & 17 & $74.0^{\mathrm{a}}$ & 0.89 & Best and Stauffer 1980 \\
\hline $\begin{array}{l}\text { Acadian Flycatcher } \\
\quad \text { (Empidonax virescens) }\end{array}$ & 138 & 30 & 13 & 64.5 & 1.46 & $\begin{array}{l}\text { Walkinshaw 1966a, } \\
\text { Mumford } 1964\end{array}$ \\
\hline $\begin{array}{l}\text { Traill's Flycatcher } \\
\quad(\text { E. traillii) }\end{array}$ & $\begin{array}{r}33 \\
92 \\
207 \\
91\end{array}$ & $\begin{array}{l}31.5 \\
31.5 \\
31.5 \\
28\end{array}$ & $\begin{array}{l}13.5 \\
13.5 \\
13.5 \\
12\end{array}$ & $\begin{array}{l}44.6 \\
65.2 \\
69.5 \\
39.5\end{array}$ & $\begin{array}{l}2.56 \\
1.36 \\
1.16 \\
3.32\end{array}$ & $\begin{array}{l}\text { King } 1955 \\
\text { Berger } 1967 \\
\text { Walkinshaw 1966b } \\
\text { Holcomb } 1972\end{array}$ \\
\hline $\begin{array}{l}\text { Least Flycatcher } \\
\quad(\text { E. minimus })\end{array}$ & 101 & 31.5 & 14 & 51.9 & 2.08 & Walkinshaw 1966c \\
\hline $\begin{array}{l}\text { Western Flycatcher } \\
\quad \text { (E. difficilis) }\end{array}$ & 28 & 34.5 & 16.5 & $67.5^{\mathrm{a}}$ & 1.14 & Davis et al. 1963 \\
\hline
\end{tabular}

a Nest success in these studies corrected for exposure time. 
TABLE 3. Nest placement of Eastern Kingbirds in New York and Kansas.

\begin{tabular}{lccc}
\hline \hline \multicolumn{1}{c}{ Variable } & New York (mean [SD]) & Kansas (mean [SD]) & $t^{*}$ \\
\hline Nest height $(\mathrm{m})$ & $6.5(4.24)$ & $7.1(4.54)$ & 0.64 \\
Distance from top $(\mathrm{m})$ & $2.7(2.22)$ & $3.4(3.08)$ & 1.39 \\
Relative height & $0.70(0.135)$ & $0.67(0.179)$ & 1.01 \\
Distance from center $(\mathrm{m})$ & $1.8(0.85)$ & $2.7(1.60)$ & $3.73^{* * *}$ \\
Distance from canopy $(\mathrm{m})$ & $0.9(0.44)$ & $1.8(1.34)$ & $4.78^{* * *}$ \\
Relative distance & $0.63(0.175)$ & $0.59(0.192)$ & 1.08 \\
Number of branches & $5.7(0.96)$ & $4.8(1.13)$ & $4.45^{* * *}$ \\
Cover & $3.1(1.04)$ & $2.8(1.18)$ & 1.53 \\
Sample size & 58 & 56 & \\
\hline a Value of $t$-test comparing mean values of nest placement variables between New York and Kansas.*** $P<0.001$. &
\end{tabular}

a Value of $t$-test comparing mean values of nest placement variables between New York and Kansas. ${ }^{* * *} P<0.001$

Empidonax traillii excluded]). The failure of some authors to account for exposure time probably inflated some estimates of success (as Ricklefs 1969a noted for his data), but the average daily mortality rate for those studies where Mayfield's (1961) correction has been applied (Table 2 ) was still low (1.68\%/day).

\section{NEST SITES}

In general, nest placement differed little between New York and Kansas. (Table 3). With the exception of the absolute distance at which nests were placed from the center and periphery of the tree, none of the major nest site characteristics differed significantly between the two regions (Table 3). Overall, nest height ranged from 2 to over $25 \mathrm{~m}$. The mean nest heights reported here did not differ significantly from the $6.8 \mathrm{~m}$ reported by MacKenzie and Sealy (1981) from Manitoba $(t=0.38, \mathrm{df}=$ 114 in New York; $t=0.33, \mathrm{df}=112$ in Kansas), but both were significantly higher ( $t=$ 10.2, $\mathrm{df}=287$ in New York; $t=11.2, \mathrm{df}=$ 285 in Kansas) than the mean nest height of $2.5 \mathrm{~m}(\mathrm{SD}=2.13, n=213)$ of Eastern Kingbirds from the Canadian Prairie Provinces (D. I. MacKenzie, pers. comm.). Although absolute nest height did not differ significantly between New York, Kansas and Delta Marsh (Manitoba), relative nest height was significantly higher in New York $(t=4.89, \mathrm{df}=114$, $P<0.001)$ and Kansas $(t=3.22, \mathrm{df}=112$, $P<0.001)$ than in Manitoba $(\bar{x}=0.57$, MacKenzie and Sealy 1981).

Most nests were placed on horizontal or diagonal branches about $60 \%$ of the distance out from the main trunk of the tree to the canopy edge (Table 3$)$. Only 1 of 114 nests $(0.9 \%)$ was placed in a main crotch of the nest tree. However, most nests at Delta Marsh, Manitoba were placed centrally (D. I. MacKenzie, pers. comm.). The same or related tree species available for nesting at Delta Marsh (see MacKenzie and Sealy 1981) were also readily available in New York and Kansas, yet they were not commonly used (i.e., only $7.0 \%$ of the time).
Nests placed in these species (Populus deltoides, Acer sp., and Fraxinus sp.) had a mean relative distance from the tree center of only $0.39(n=8)$. These trees, apparently, did not offer horizontal attachment sites that were as suitable as in those other species used much more frequently (Morus sp., Ulmus sp., Maclura pomifera and Malus sp.; 56\%), suggesting that placement of the nest away from the main trunk was preferred.

Distance of the nest from the top of the tree was directly correlated with distance from the center of the tree in both New York $(r=0.482$, $\mathrm{df}=56, P<0.001)$ and Kansas $(r=0.520$, $\mathrm{df}=54, P<0.001)$, indicating that as nests were placed lower, they were situated farther from the main trunk of the tree. This finding is supported by two additional observations: the direct correlation between nest height and distance from the canopy edge in Kansas ( $r=$ $0.485, \mathrm{df}=54, P<0.001)$ and the inverse correlation between relative nest height and distance from the center of the tree in New York $(r=-0.411, \mathrm{df}=56, P<0.001)$. Thus, selection of nest sites low in trees, or placement of nests in small trees was usually accompanied by placement of nests in extreme positions away from the tree center, generally on long horizontal branches. Vegetative cover around the nest was inversely correlated with nest height in New York $(r=-0.262, \mathrm{df}=56$, $P<0.05)$ and distance from the tree center in Kansas $(r=-0.303, \mathrm{df}=54, P<0.05)$. Nests placed near the top of the tree, or close to the canopy edge therefore tended to be less protected from wind, sun or rain.

Principal component analysis of the Eastern Kingbird data also indicated that significant patterns of covariation existed among nest placement variables. The first principal component explained 29.5 and $30.8 \%$ of the original variation in nest placement in New York and Kansas, respectively. In New York, as relative nest height decreased, distance from the top of the tree increased. At the same time, absolute nest height tended to increase. This 

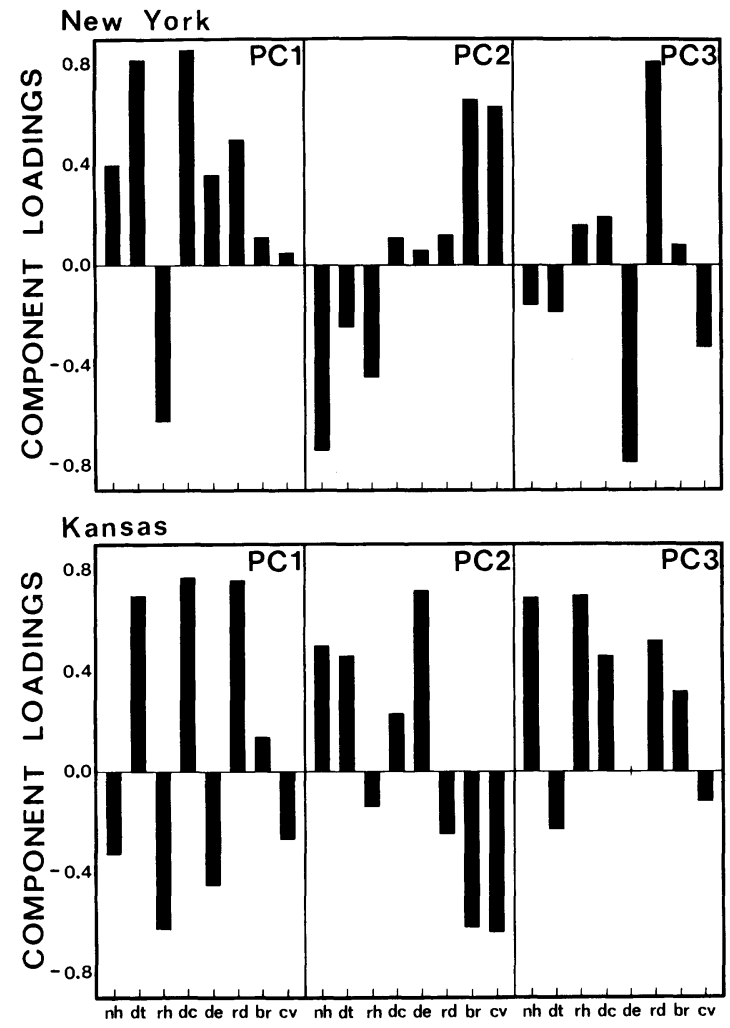

NEST PLACEMENT VARIABLES

FIGURE 1. Principal component loadings from the analysis of placement of nests in New York and Kansas. $\mathrm{PCl}, \mathrm{PC} 2$ and $\mathrm{PC} 3$ refer to Principal Components 1,2 and 3 , respectively. Abbreviations for nest placement variables are: $n h$, nest height; $d t$, distance of nest from top of tree; $r h$, relative nest height; $d c$, distance of nest from center of tree; de, distance of nest from canopy edge; $r d$, relative distance of nest from center of tree, $b r$, number of branches supporting nest; $c v$, vegetative cover around nest.

pattern of nest placement was usually also accompanied by placement of the nest farther from the tree center, in both a relative and absolute sense (Fig. 1). I found a similar pattern for Kansas. As relative nest height decreased, distance from the top of the tree increased and both absolute and relative distance from the center of the tree increased (Fig. 1). Thus, for both populations, I interpreted PC1 as a contrast of the horizontal and vertical components of nest placment. Principal Component 2 in New York explained $20.8 \%$ of the original variation, and contrasted relative and absolute nest height with the microhabitat nest placement variables (i.e., number of supporting branches and vegetative cover). It indicated that nests placed lower in the tree generally had more cover and more supporting branches than nests placed higher (Fig. 1). Principal Component 2 explained $23.9 \%$ of the original variation in Kansas nest placement data. This axis indicated that cover and number of supporting branches tended to decrease as absolute nest height and distance from the top of the tree and canopy edge increased (Fig. 1). Principal Component 3 explained 18.8 and $20.3 \%$ of the variation in nest placement in New York and Kansas, respectively, and in New York contrasted distance from the canopy edge with relative distance from the tree center (Fig. 1). Principal Component 3 in Kansas contrasted nests placed absolutely and relatively high in a tree, and absolutely and relatively far from the tree center, with nests placed low and close to the tree center.

The contrast of the horizontal and vertical components of nest placement by $\mathrm{PCl}$ was similar to the species-specific patterns of nest placement found within other flycatchers $(\mathrm{Ta}$ ble 4). With the exception of the Yellow-bellied Flycatcher, all open-nesting tyrannids place their nests in trees or bushes, $2 \mathrm{~m}$ or more above the ground. Those species nesting at lower heights usually place their nests close to the canopy edge (e.g., Acadian Flycatcher and Scissor-tailed Flycatcher; Table 4). The alternative, that of placing nests near the top of the tree but close to the main trunk, is used by the Least Flycatcher, Western Kingbird and Cassin's Kingbird (Table 4). The wide range of nest heights of species in the genus Tyrannus, especially the Eastern Kingbird, indicates that nest height depends to some extent upon the availability of suitable nest trees (Table 4; D. I. MacKenzie, pers. comm.). However, the four Tyrannus species (included at the top of Table 4) clearly demonstrate the inverse relationship between nest height and distance from the center of the tree.

\section{NEST PLACEMENT AND SUCCESS}

Nest success was significantly correlated with nest placement variables in New York only (Table 5). However, in all cases comparisons between failed and successful nests in Kansas tended to be in the same direction as in New York. Successful nests were placed at lower absolute and relative heights than failed nests, and also had significantly more surrounding cover and supporting branches in New York (Table 5). Thus, lower success was associated with greater exposure of the nest, due either to less vegetative cover around the nest, or placement in increasingly extreme positions in the tree (i.e., closer to the peak). Relative distance from the center of the tree and relative nest height in Kansas were apparently not associated with success (Table 5).

I combined samples from both sites in order to further examine the relationship between success and relative height and distance from 
TABLE 4. Nest placement of open-nesting tyrant flycatchers breeding in North America.

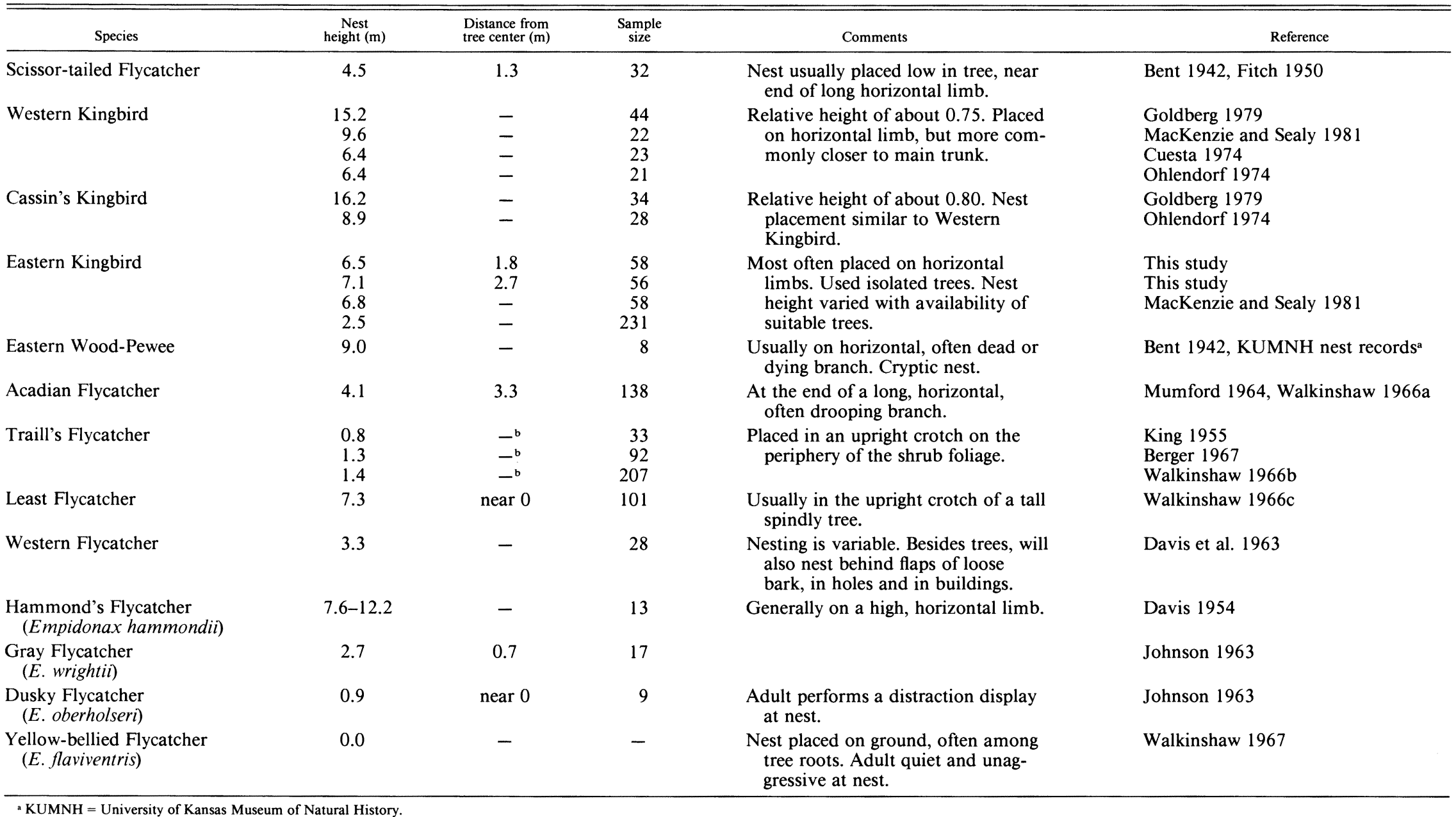




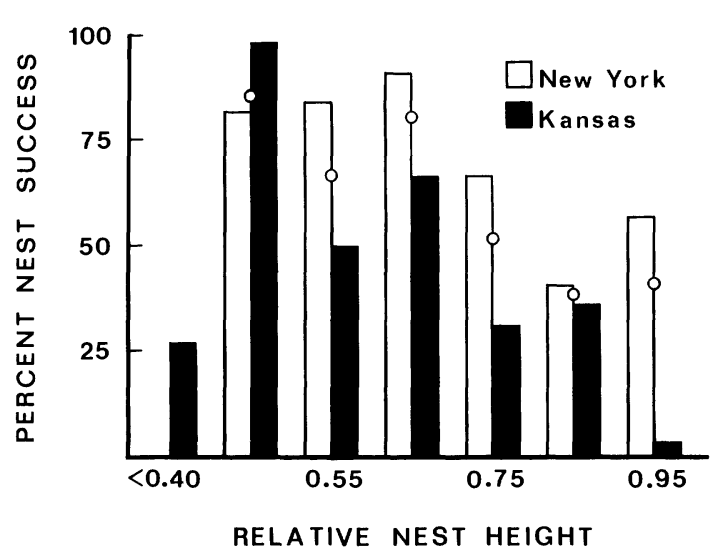

FIGURE 2. Nest success in relation to relative nest height. All nests below a relative height of 0.41 are grouped into a single class. Values for other height classes are midpoints for intervals. Circles indicate weighted average nest success for New York and Kansas samples.

the tree center. This was justified since success varied in a similar manner with both variables in both populations. Nests were most successful between the relative heights of 0.41 and 0.71 in both populations (Fig. 2). However, above a relative height of 0.41 , nest success tended to decrease and a significant inverse relationship existed between percent nest success and relative nest height $(r=-0.897, \mathrm{df}=$ $4, P<0.05$ ). In addition to the low success of nests placed relatively high, nests placed below a relative height of 0.41 in Kansas were also very unsuccessful (Fig. 2). No nests were placed this low in New York. Exclusion of nests placed below a relative height of 0.41 in Kansas indicated that failed nests were placed relatively higher than successful nests $(t=2.43, \mathrm{df}=44$, $P<0.05$ ), as was also found earlier in New York. Similarly, nest success also tended to decrease as relative distance of the nest from the tree center increased (Fig. 3). Nests placed closest to the canopy edge were the most likely to fail in both New York and Kansas. However, of the five nests placed very close to the center of the tree in Kansas (relative distance $<0.31$ ), only one fledged young, suggesting that placement of the nest very close to the tree center was also likely to result in the failure of the nest. The lack of a difference between successful and failed nests in relation to relative nest height and distance from the tree center in Kansas (Table 5) was therefore due to the increased probabilities of nest failure both above and below the average sites of placement.

Principal component analysis of the data indicated that the suite of variables associated with PC2 and PC3 (but not PC1) differed between failed and successful nests. The fact that

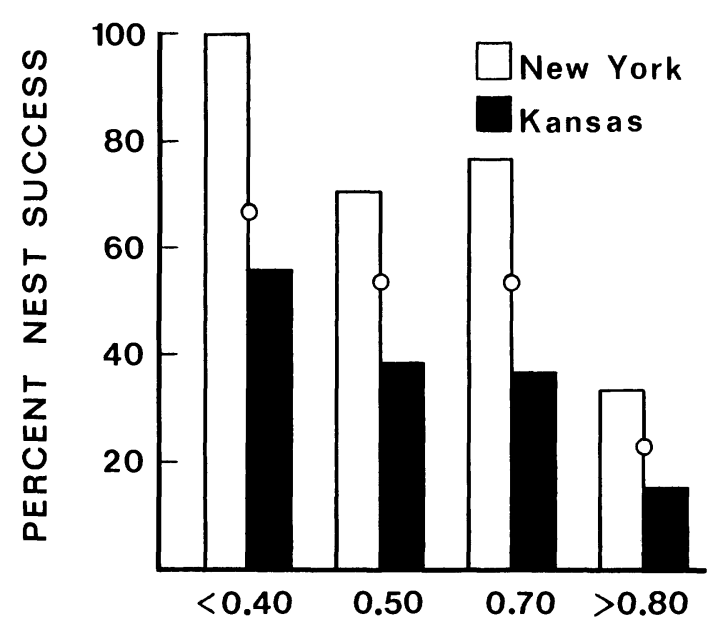

RELATIVE NEST DISTANCE

FIGURE 3. Nest success in relation to relative distance of nest from center of tree. All nests closer than relative distance of 0.41 to tree center are grouped into a single class, as are all nests greater than a relative distance of 0.80 . Values given for other classes are midpoints for intervals. Circles indicate weighted average nest success for New York and Kansas samples.

the component scores of successful and failed nests did not differ on $\mathrm{PCl}$ indicated that the horizontal and vertical components of nest placement did not by themselves determine the probability of success. Instead, the simultaneous action of nest height, cover and number of supporting branches was more important in determining nest fates. Failed and successful nests were clearly separated on PC2 in New York (Table 6; Fig. 4). Successful nests were thus placed relatively lower with more cover and supporting branches. Mean scores for failed nests on PC2 in Kansas indicated that they also tended to be placed relatively higher in the tree and to have less vegetative cover, and also to be placed farther from the canopy edge than successful nests (Table 6; Fig. 4 ), but the difference only approached significance $(P=0.11)$. Removal of the five relatively low nests (relative nest height $<0.41$ ) indicated that the difference was nearly significant $(t=1.88, \mathrm{df}=44, P=0.07)$.

In New York, the component scores of successful and failed nests on PC3 were not quite significantly different (Table 6; Fig. 4). However, the scores indicated that successful nests tended to be placed farther from the canopy edge and closer to the tree center than failed nests. The difference between the two classes of nests on PC3 in Kansas was also not significantly different (Table 6; Fig. 4). Hence, high nests far from the tree center were just as likely to fledge young as were low nests close to the tree center. However, exclusion of the 
TABLE 5. Comparison of the placement of successful and failed Eastern Kingbird nests in New York and Kansas.

\begin{tabular}{|c|c|c|c|c|c|c|}
\hline \multirow[b]{2}{*}{ Variable } & \multicolumn{3}{|c|}{ New York (mean[SD]) } & \multicolumn{3}{|c|}{ Kansas (mean[SD]) } \\
\hline & Successful & Failed & $t^{\mathrm{a}}$ & Successful & Failed & $t^{a}$ \\
\hline Nest height $(\mathrm{m})$ & $5.9(4.10)$ & $7.8(4.48)$ & 1.46 & $6.1(2.63)$ & $7.9(5.56)$ & 1.55 \\
\hline Distance from top (m) & $2.9(2.40)$ & $2.4(1.63)$ & 0.83 & $3.0(1.37)$ & $3.6(3.96)$ & 0.77 \\
\hline Relative height & $0.68(0.131)$ & $0.77(0.125)$ & $2.46^{*}$ & $0.66(0.152)$ & $0.69(0.197)$ & 0.58 \\
\hline Distance from center $(\mathrm{m})$ & $1.7(0.85)$ & $1.9(0.86)$ & 0.57 & $2.3(1.26)$ & $3.0(1.84)$ & 1.71 \\
\hline Distance from canopy (m) & $1.0(0.42)$ & $0.9(0.55)$ & 0.63 & $1.7(0.58)$ & $2.0(1.69)$ & 0.91 \\
\hline Relative distance & $0.61(0.183)$ & $0.68(0.141)$ & 1.67 & $0.55(0.176)$ & $0.60(0.206)$ & 0.97 \\
\hline Number of branches & $6.0(0.92)$ & $5.0(0.76)$ & $3.90^{* * *}$ & $5.2(1.23)$ & $4.6(0.88)$ & 1.70 \\
\hline Cover & $3.4(0.99)$ & $2.5(0.83)$ & $3.40^{* * *}$ & $3.0(1.36)$ & $2.7(1.10)$ & 0.80 \\
\hline Sample size & 42 & 15 & & 20 & 31 & \\
\hline
\end{tabular}

a Value of $t$-test comparing mean scores between failed and successful nests. ${ }^{*} P<0.05 ;{ }^{* * *} P<0.001$

five relatively low nests again nearly established a significant difference between the two groups $(t=1.85, \mathrm{df}=44, P=0.075)$, suggesting that high nests close to the canopy edge were more likely to fail. Although significant differences were found in only one of the two sites, and for only one component, the results of the principal components analyses were consistent with univariate comparisons in associating lower relative height, greater amounts of vegetative cover, and increased distance from the canopy edge with increased probabilities of success.

The duration of the nestling periods and nest heights used to test the predator avoidance theory for nest site selection were taken from Tables 2 and 4, respectively. A significant positive relationship exists between length of the nestling period and nest height $(r=0.606, \mathrm{df}=$ $11, P<0.05)$. However, nestling period duration and adult body weight are also correlated, though not significantly in these species $(r=0.487, \mathrm{df}=11, \mathrm{~ns})$. The correlation of nestling period duration with nest height may therefore be an artifact of a relationship between body weight and nest height. However, the latter correlation is not significant $(r=$ 0.467 , df $=11$ ). These results support the predator avoidance hypothesis, and strongly suggest that flycatchers compensate for greater risks of predation as the length of exposure increases by making nests less accessible to ground predators, and most mammalian predators. I could not find quantitative data for two additional species (Western Wood-Pewee, Contopus sordidulus, and Olive-sided Flycatcher, $C$. borealis) that have long nestling periods ( $\geq 17$ days). Both typically place their nests high in trees, usually on horizontal limbs (Bent 1942). Peewees (Contopus spp.) also commonly build their nests on dead or dying branches, and cover parts of the nest exterior with lichens, apparently in order to cryptically pattern the nest (Bent 1942; M. T. Murphy, pers. observ.).

\section{DISCUSSION}

Inaccessible, secure nest sites should be at a premium when time constraints limit opportunities for breeding and environmental factors limit rates of growth. Tyrant flycatchers breed relatively later (Robins 1970) and have longer nesting cycles than most other north temperate breeding, open-nesting passerines (Table 2). Their breeding seasons are therefore relatively short and only three species of phoebes (Sayornis spp.) are able to raise two broods per year (Bent 1942, Robins 1970). In the Eastern Kingbird, nests that fail at the nestling stage are most often not replaced (Murphy, in press). Specialized nesting habits are therefore to be expected in this family and information on nest placement presented here supports this argument, the strongest support coming from the significant relationship between nest height and duration of the nestling period. The relatively high nest success apparently characteristic of the family in North

TABLE 6. Mean factor scores on Principal Components 1, 2 and 3 for successful and failed nests in New York and Kansas.

\begin{tabular}{|c|c|c|c|c|c|c|c|c|}
\hline & \multicolumn{4}{|c|}{ New York (mean [SD]) } & \multicolumn{4}{|c|}{ Kansas (mean [SD]) } \\
\hline & $\mathrm{PC1}$ & PC2 & PC3 & $n$ & PC1 & PC2 & PC3 & $n$ \\
\hline Successful & $0.02(1.042)$ & $0.26(0.958)$ & $-0.14(0.918)$ & 42 & $-0.08(0.730)$ & $-0.28(0.839)$ & $-0.23(0.835)$ & 20 \\
\hline Failed & $-0.06(0.901)$ & $-0.74(0.714)$ & $0.40(1.139)$ & 15 & $0.05(1.150)$ & $0.18(1.164)$ & $0.15(1.081)$ & 31 \\
\hline$t$-value & 0.29 & $3.71^{* * *}$ & 1.85 & & 0.48 & 1.66 & 1.32 & \\
\hline
\end{tabular}




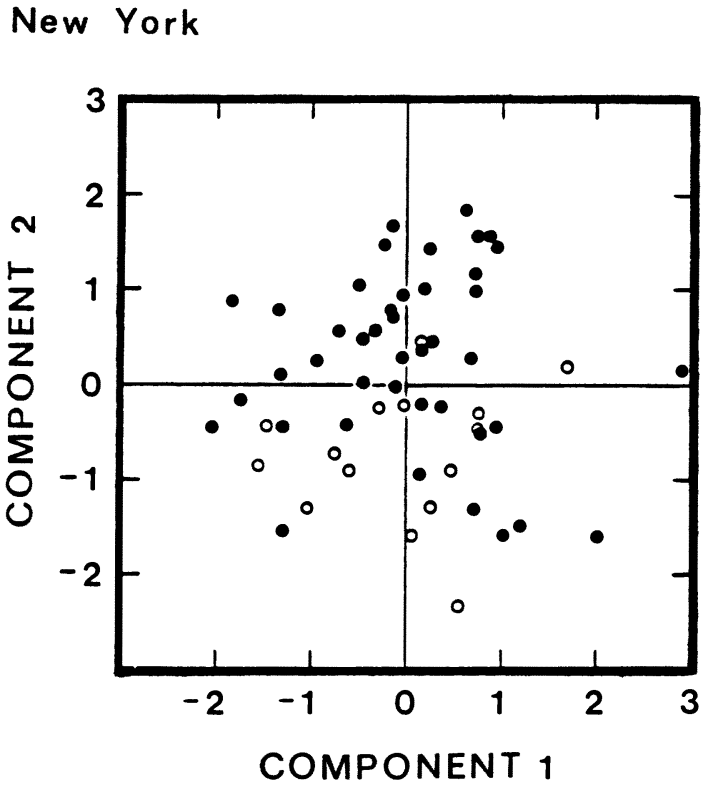

Kansas

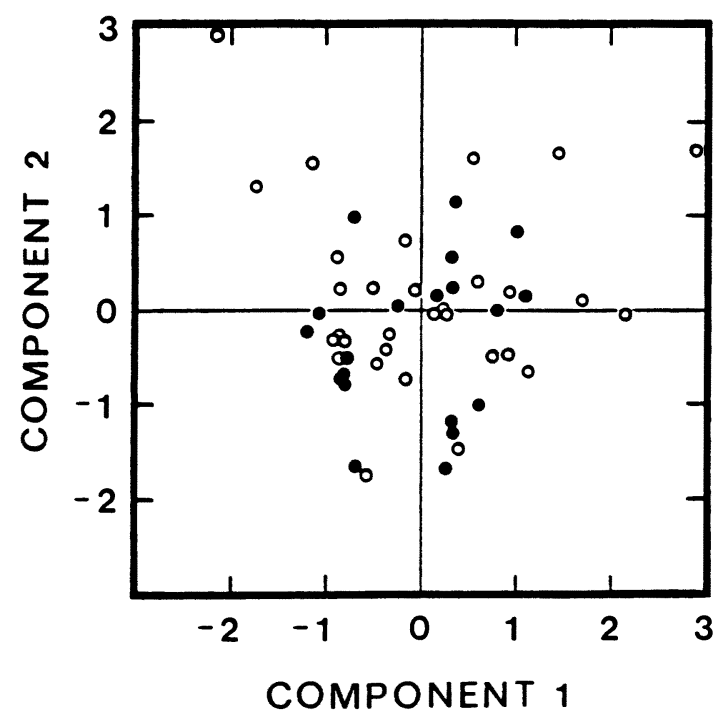

New York

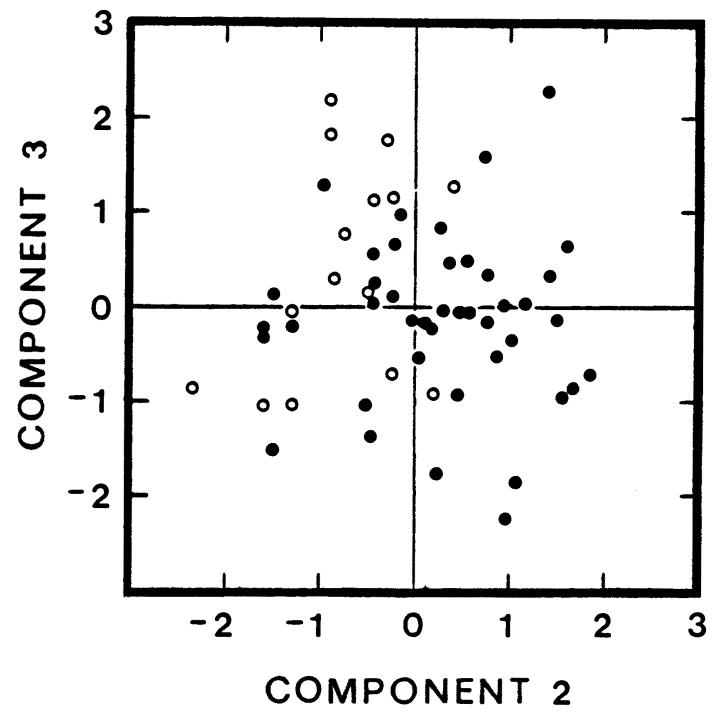

Kansas

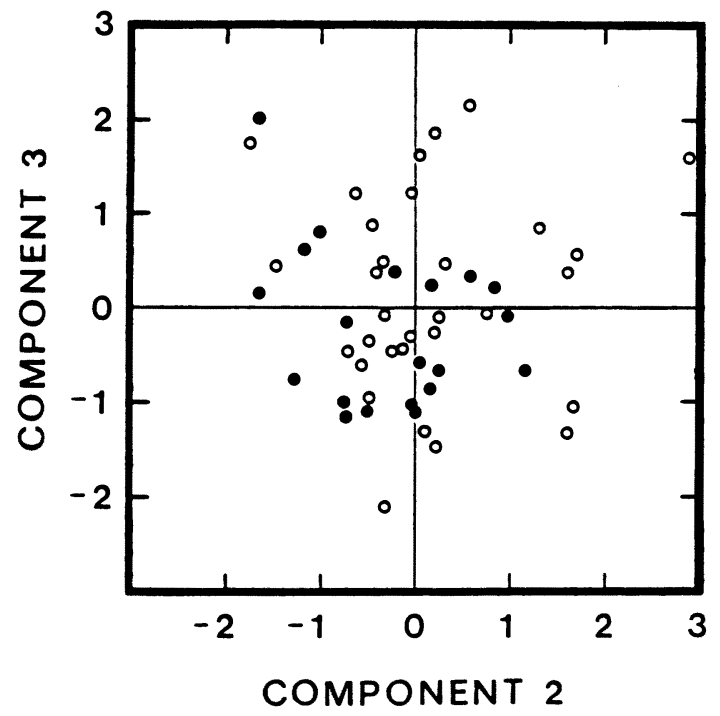

FIGURE 4. Bivariate plots of component scores for successful (closed circles) and unsuccessful (open circles) nests on Principal Components 1 and 2, and 2 and 3 in New York and Kansas. Mean values for both classes of nests on all three components are given in Table 6.

America suggests that the nest placement behaviors adopted by these species are effective means of reducing nest losses.

Patterns observed in my study suggest that predation is the driving force behind nest site selection. First, it is the major cause of nest failures in the Eastern Kingbird. Kingbird nests placed relatively low had the least probability of fledging young, due almost solely to the activities of predators $(80 \%$ of losses below a relative height of 0.41 ). Low nests were presumably more accessible, possibly because they were more visible to ground predators, and/or the larger lower limbs offered more support for their movements. In addition, nests placed extremely high in trees usually also failed. Similarly, except for the low success $(20 \%, n=5)$ of nests placed near the trunk in Kansas, nest success was inversely related to relative distance from the center of the tree. Exposure to physical factors (high winds and intense sunlight) was probably more severe at higher levels in trees or at the ends of branches where vegetation and supporting branches are thinner and weaker. If predators were absent, nests placed relatively low or close to the trunk would pre- 
sumably be most successful. The complete absence of nests below a relative height of 0.41 in New York and the low percentage in Kansas $(10 \%)$ suggests that these nest sites are susceptible to predation. Low sites are apparently shunned by Eastern Kingbirds. Maximum success thus occurred at mid-heights in the tree and about midway between the tree center and canopy edge, indicating that those sites most heavily used were also generally the most successful. Nest placement behavior therefore probably represents a compromise between balancing losses to predators and weather. It seems to act in a manner analogous to stabilizing selection since at one extreme (low nests, close to trunk) predators are able to easily reach nests, but at the other (high nests or near the canopy edge) damage or loss of nests to physical factors increases.

However, results of the principal components analyses of Eastern Kingbird nests indicated that success was equally high among nests placed low in trees when placed on long horizontal branches, and those placed at the tops of trees, but relatively closer to the main trunk. Both positions are apparently difficult for nonflying predators to reach, probably because of the weakness of the branches at those sites (for an example see Walkinshaw 1966a: 255). Vegetative cover around the nest, and the number of supporting branches are apparently important determinants of success and it is their interaction with relative and absolute nest heights and distance from the canopy edge that are most important in determining success. These results suggest that the different nest sites used by these flycatchers provide equally effective means of hiding from predators. The actual site where each species places its nest probably reflects the range of suitable sites available to it within the tree species normally found in the habitats and geographic ranges where each species evolved. For example, within the genus Tyrannus, the Scissortailed Flycatcher has the lowest average nest height and the Western and Cassin's kingbirds the highest. The former species occupies open, grassland habitats (Smith 1966; M. T. Murphy, pers. observ.) where average tree height is low. The latter two species often nest along river courses in the west where tree height averages considerably higher (Smith 1966). The Eastern Kingbird is perhaps the most catholic in its choice of nest sites, possibly because of the great diversity of habitats encountered over its broad geographic range (see Fig. 1 in MacKenzie and Sealy 1981).

Adult defense of the nest may also contribute to high nest success in these species. Tyrannids are well known for their aggressiveness
(Bent 1942), and both Davis (1941) and MacKenzie and Sealy (1981) stated that the most violent Eastern Kingbird interactions occur intraspecifically at the nest site. MacKenzie and Sealy (1981) also suggested that Eastern Kingbird aggression occurs in relation to competition for nest sites. However, kingbirds ( $T y$ rannus spp.) also aggressively defend their conspicuous nests against predators. Ricklefs (1977a) detected a strong correlation between nest conspicuousness and intensity of nest defense in tropical passerines. Conspicuous nests are generally placed peripherally, and as Ricklefs (1977a) suggested, the extra defense required by conspicuous nests is probably aided by this peripheral placement since it affords air space in which aerial foragers with powerful flight abilities can maneuver. Eastern Kingbirds watch vigilantly over their nests (Smith 1966; M. T. Murphy, pers. observ.), regularly intercepting potential nest predators over 100 $\mathrm{m}$ from the nest and forcing them from the area. I have seen flying Blue Jays (Cyanocitta cristata) driven to the ground and, on one occasion, knocked off a perch by an Eastern Kingbird. Crows and squirrels are similarly harassed. Western Kingbirds are nearly as aggressive and both have repeatedly struck me while I weighed nestlings at nests. While numerous species are occasionally attacked, corvids and other avian predators are the species most frequently the objects of the most persistent and aggressive interspecific attacks by Eastern Kingbirds.

Reproductive effort, of which nest defense is a component, is predicted to vary inversely with the potential for future breeding attempts (e.g., as individuals age or as the end of the breeding season approaches; Pianka and Parker 1975, Ricklefs 1977b). Short-lived individuals (e.g., passerine birds; Farner 1955) with restricted breeding seasons (tyrant flycatchers; Robins 1970; Murphy, in press) should invest relatively greater amounts of time and energy in each breeding attempt than should individuals with more than one opportunity for breeding per season. The intense aggression over nest sites and the presumed high risks associated with nest defense in tyrannids would therefore be predicted from the limited breeding opportunities that most species have. Eastern Kingbirds differ in their intensity of nest defense and more aggressive pairs have higher nest success (Blancher and Robertson 1982). The ability of kingbirds and other flycatchers to engage in aggressive nest defense is probably aided by the peripheral placement of the nest and their powerful flight abilities.

The hypothesis that tyrannid aggressiveness is related to nest defense is supported by one 
case of its complete absence. Adult Yellowbellied Flycatchers, which place their nests on the ground (Bent 1942), are quiet and unobtrusive around the nest, and nests are apparently difficult to find (Walkinshaw 1967). Since these birds would have little chance of deterring most terrestrial predators, it seems likely that they have evolved an alternative habit of anonymity in the nesting area so as to reduce the chance of attracting predators to the nest. Behavior at the nest and nest placement ar therefore likely coevolved traits, and are the primary means of reducing nest losses.

These findings indicate that even within the same habitats, not all species are necessarily exposed to the same risks of predation. Selec tion of particularly safe nest sites and/or aggressive nest defense are methods by whic $\rightarrow$ rates of nest loss can be reduced, suggesting a basis for the intense intraspecific competition for nest sites by Eastern Kingbirds. However, the efficacy of nest site selection to reduce nest losses is not always realized. Hence, it is not justified to assume, as has sometimes been done, that all things are equal among opennesting passerines. Different risks of nest loss cast doubt on models of life history evolution based on this premise, an example being the hypothesis that growth rates of nestling passerines are pushed to the physiological maxi mum because of the intensity of predator pressure (Ricklefs 1969b). Unquestionably, high rates of nest predation will select for faster nestling growth and early fledging, but other constraints on the rate of nestling development (e.g., foraging mode; O'Connor 1978) may not allow such increases in growth rate. The specialized foraging techniques of most tyrant flycatchers generally result in low rates of encounters with prey (Fitzpatrick 1981), which may be further worsened by inclement weathe (Mahan 1964). The prediction that nestling growth rates should drop under such conditions (O'Connor 1978) is in general supported by the available information (Ricklefs 1976; Murphy 1981, in press). Nest site selection apparently provides a mechanism to allow such reductions in the rate of nestling development.

\section{ACKNOWLEDGMENTS}

I thank M. Gaines, R. F. Johnston, P. E. Lowther and O. $R$. Taylor for reading and commenting on earlier drafts of this paper. Constructive criticisms were also given $b-$ R. C. Fleischer, M. Holmgren, and W. B. MacGillivray. The late David MacKenzie provided a prepublication copy of his paper and additional information on nest placement in Eastern Kingbirds from his study area. His comments on an earlier draft are also appreciated. The Northeaster $\rightarrow$ Bird-Banding Association and the Bird Division at the Museum of Natural History at the University of Kansas provided funds. The help of my wife, Karmel Licata, throughout this research was invaluable.

\section{LITERATURE CITED}

BART, J. 1978. Impact of human visitation on avian nesting success. Living Bird 16:187-192.

BENT, A. C. 1942. Life histories of North American flycatchers, larks, swallows and their allies. U.S. Natl. Mus. Bull. 179.

Berger, A. J. 1967. Traill's Flycatcher in Washtenaw County, Michigan. Jack-Pine Warbler 45:117-123.

Best, L. B., AND D. F. Stauffer. 1980. Factors affecting nesting success in riparian bird communities. Condor 82:149-158.

Blancher, P. J., And R. J. Robertson. 1982. Kingbird aggression: does it deter predation? Anim. Behav. 30: 929-930.

Cuesta, L. R. 1974. Comparative breeding ecology of the Western Kingbird (Tyrannus verticalis) in three habitat types. M. Sc. thesis, New Mexico State Univ., Las Cruces.

Davis, D. E. 1941. The belligerency of the kingbird. Wilson Bull. 53:157-168.

Davis, D. E. 1954. The breeding biology of Hammond's Flycatcher. Auk 71:164-171.

Davis, J., G. F. Fisler, And B. S. Davis. 1963. The breeding biology of the Western Flycatcher. Condor 65:337-382.

Dixon, W. J., AND M. B. Brown [eds.]. 1979. BMPD79: biomedical computer programs, P-series. Univ. of California Press, Berkeley.

FARNER, D. S. 1955. Birdbanding in the study of population dynamics, p. 397-449. In A. Wolfson [ed.], Recent studies in avian biology. Univ. of Illinois Press, Urbana.

Fiтch, F. W. 1950. Life history and ecology of the Scissor-tailed Flycatcher, Muscivora forficata. Auk 67:145168.

FItzPATRICK, J. W. 1981. Search strategies of tyrant flycatchers. Anim. Behav. 29:810-821.

GoldBerG, N. H. 1979. Behavioral flexibility and foraging strategies in Cassin's and Western kingbirds (Tyrannus vociferans and $T$. verticalis) breeding sympatrically in riparian habitats in central Arizona. Ph.D. diss., Univ. of Illinois, Champaign.

Holcomв, L. C. 1972. Traill's Flycatcher breeding biology. Nebr. Bird Rev. 40:50-68.

Johnson, N. K. 1963. Biosystematics of sibling species of flycatchers in the Empidonax hammondi-oberholseri-wrightii complex. Univ. Calif. Publ. Zool. 66:79238.

JoHnson, D. H. 1979. Estimating nest success: the Mayfield method and an alternative. Auk 96:651-661.

KING, J. R. 1955. Notes on the life history of Traill's Flycatcher (Empidonax traillii) in southeastern Washington. Auk 72:148-173.

LACK, D. 1968. Ecological adaptations for breeding in birds. Methuen Press, London.

MacKenzie, D. I., and S. G. Sealy. 1981. Nest site selection in Eastern and Western kingbirds: a multivariate approach. Condor 83:310-321.

Mahan, H. D. 1964. The effects of the environment on growth, development and temperature regulation in nestling Eastern Phoebes. Ph.D. diss., Michigan State Univ., East Lansing.

Mayfield, H. F. 1961. Nesting success calculated from exposure. Wilson Bull. 73:255-261.

Mumford, R. E. 1964 . The breeding biology of the Acadian Flycatcher. Misc. Publ. Mus. Zool. Univ. Mich., 125.

Murphy, M. T. 1981. Growth and aging of nestling Eastern Kingbirds and Eastern Phoebes. J. Field Ornithol. 52:309-316.

MurPhy, M. T. In press. The breeding biology of Eastern Kingbirds: geographic comparisons. Ecology. 
Nolan, V., JR. 1963. Reproductive success in birds in a deciduous forest scrub habitat. Ecology 44:305-313.

O'CoNNOR, R. J. 1978. Growth strategies of nestling passerines. Living Bird 16:209-238.

OHLENDORF, H. M. 1974. Competitive relationships among kingbirds (Tyrannus) in Trans-Pecos Texas. Wilson Bull. 86:357-373.

Pettingill, O. S., JR. 1973. Exceptional nest sites of the Eastern Kingbird. Jack-Pine Warbler 51:124-126.

Pianka, E. R., and W. S. Parker. 1975. Age-specific reproductive tactics. Am. Nat. 109:453-464.

RiCKLEFS, R. E. 1969a. An analysis of nesting mortality in birds. Smithson. Contrib. Zool. 9.

RiCKLEFs, R. E. 1969b. Preliminary models for growth rates of altricial birds. Ecology 50:1031-1040.

$\rightarrow$ RiCKLEFs, R.E. 1976. Growth rates of birds in the humid New World tropics. Ibis 118:179-207.

Ricklefs, R. E. 1977a. Reactions of some Panamanian birds to human intrusion at the nest. Condor 79:376379.

$\rightarrow$ RickLEFs, R. E. 1977 b. On the evolution of reproductive strategies in birds: reproductive effort. Am.Nat. 111: $453-478$

Robins, J. D. 1970. The relationship of food supply to the timing of breeding in aerial foragers. Kansas Ornithol. Soc. Bull. 21:9-15.

Condor 85:219

c) The Cooper Ornithological Society 1983

\section{RECENT PUBLICATIONS}

Habitat Use and Productivity of Canvasbacks in Southwestern Manitoba, 1961-72.-Jerome H. Stoudt. 1982. U.S. Fish and Wildlife Service, Special Scientific ReportWildlife, No. 248.31 p. Paper cover. Representing twelve years of observation which ended more than a decade ago, this paper is largely a historical study. Thirty-three tables of observational data compose the bulk of the report. An editorial footnote on current conditions in the Minnedosa area would have been valuable. Appendix $A$ is a list of common and scientific names of plants and animals. Appendix $B$ is a phenology of the breeding season for selected organisms in the study area. Photographs, and a list of references (but not all citations used). -J. Tate.

Effects of Soils and Grazing on Breeding Birds of Uncultivated Upland Grasslands of the Northern Great Plains. H. A. Kantrud and R. L. Kologiski. 1982. U.S. Fish and Wildlife Service. Wildlife Research Report 15.33 p. Paper
Rohwer, S. A., AND D. L. Kilgore, JR. 1973. Interbreeding in the arid-land foxes, Vulpes velox and $V$. macrotis. Syst. Zool. 22:157-165.

Smith, W. J. 1966. Communications and relationships in the genus Tyrannus. Publ. Nuttall Ornithol. Club. 6.

SoKal, R. R., and F. J. Rohlf. 1981. Biometry. W. H. Freeman, San Francisco.

von HAartman, L. 1957. Adaptations in hole-nesting birds. Evolution 11:339-347.

$\rightarrow$ Walkinshaw, L. C. 1966a. Studies of the Acadian Flycatcher in Michigan. Bird-Banding 37:227-257.

Walkinshaw, L. C. 1966b. Summer biology of the Traill's Flycatcher. Wilson Bull. 78:31-46.

Walkinshaw, L. C. 1966c. Summer observations of the Least Flycatcher in Michigan. Jack-Pine Warbler 44: 150-168.

Walkinshaw, L. C. 1967. The Yellow-bellied Flycatcher in Michigan. Jack-Pine Warbler 45:2-9.

Museum of Natural History, Department of Systematics and Ecology, University of Kansas, Lawrence, Kansas 66045. Received 1 February 1982. Final acceptance 20 December 1982

cover. No price given. This study of native grassland bird populations and their habitat follows standard formats, resulting in useful data that are analyzed with appropriate statistical methods. The taxonomy and nomenclature of soils is difficult at best, and the number of independent variables that make up a given soil type is large. The authors provide an excellent summary of the first problem, and ignore the second. The resulting discussion of the interrelationships among native grassland, birds, soils, and grazing is interesting, and supported whenever possible. The evident optimum breeding habitat presented for each of 29 bird species is garnered from literature and observational sources, and from generalized results supported by the data. The conclusions are, for the most part, meaningful statements of the relationship between each grassland bird and its habitat. A small but valuable paper for anyone interested in the birds of our Northern Great Plains. References. -J. Tate. 